
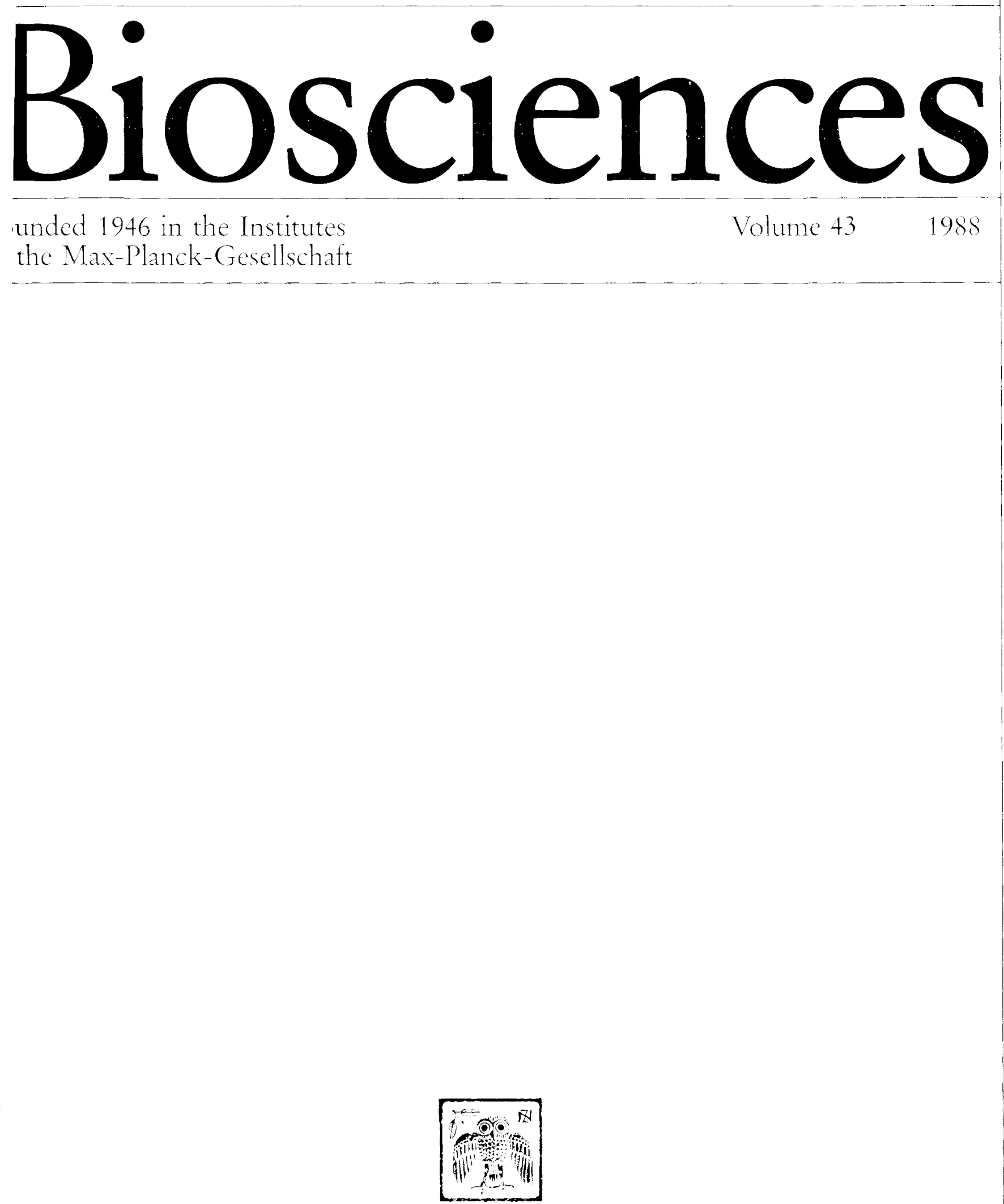

Verlag der Zeitschrift für Naturforschung 


\section{Contents}

Contents of Number $1 / 2$

Original Communications

Biflavones from Some Mosses

H. Geiger, S. Anhut, and H. D. Zinsmeister

Coumestans from the Roots of Pueraria mirifica J. L. Ingham, S. TahaRA, and S. Z. Dziedzic

In vivo Synthesis of $\left[{ }^{14} \mathrm{C}\right]$ Dilinoylgalactosylglycerol by Gametophytes of the Fern Anemia phyllitidis

E. Klose and A. R. Gemmrich

Arachidonic Acid in the Lipids of Marine Algae Maintained under Blue, White and Red Light

S. S. Radwan, A.-S. ShaAban, and H. M. GeBREEL.

Epicuticular Wax of Euphorbia aphylla Brouss. ex. Willd., Euphorbiaceae

P.-G. Gülz, J. Bodden, E. Müller, and F.-J. MARNER

Novel Sesquiterpene Ethers from Liquid Cultures of the Wood-Rotting Fungus Lentinus lepideus

W.-R. Abraham, H.-P. Hanssen, and C. MöhRINGER

Synthesis of Racemic $\left[2-{ }^{14} \mathrm{C}\right] \mathrm{Jasmonic}$ Acid H.-D. KNÖFEL and D. GRoss

Enzymic Synthesis of Hydroxycinnamic Acid Esters of Glucaric Acid and Hydroaromatic Acids from the Respective 1-O-Hydroxycinnamoylglucoside and Hydroxycinnamoyl-Coenzyme A Thioester as Acyldonors with a Protein Preparation from Cestrum elegans Leaves

D. Strack, W. Gross, J. Heilemann, H. Keller, and S. OHM

Cell Wall-Bound Phenolics from Norway Spruce (Picea abies) Needles

D. Strack, J. Heilemann, E.-S. Klinkott, and V. WRAY
Production and Accumulation of Phenylpropanoids in Tissue and Organ Cultures of Pimpinella anisum

J. Reichling, R. MARTIN, and U. ThroN

42

Fatty-Acid Biosynthesis and Acetyl-CoA Carboxylase as a Target of Diclofop, Fenoxaprop and other Aryloxy-phenoxy-propionic Acid Herbicides K. KobeK, M. Focke, and H. K. LichtenthaleR

Energy Transfer within PC Trimers of Mastigocladus laminosus Studied by Picosecond Time-Resolved Transient Absorption Spectroscopy

S. Schneider, P. Geiselhart, S. Siebzehnrübl,

R. FISCHER, and H. SCHEER

Topography of the Phytochrome Molecule as Determined from Chemical Modification of SH-Groups P. H. Eilfeld, G. Widerer, H. Malinowski, W. RÜDIGER, and P. G. EILFELD

Degree of Saturation of Blood Plasma in Vertebrates with Octocalcium Phosphate

F. C. M. Driessens, R. M. H. Verbeeck, J. W. E. van DiJK, and J. M. P. M. Borggreven

The Complete Amino Acid Sequences of the B 800-850 Antenna Polypeptides from Rhodopseudomonas acidophila strain 7750

I. Bissig, R. A. Brunisholz, F. Suter, R. J. Cogdell, and H. Zuber

Conformational Studies of Biliproteins from the Insects Pieris brassicae and Cerura vinula H. SCHEER and H. KAYSER

Selective Binding of Amino Acid Residues to tRNA Molecules Detected by Anticodon-Anticodon Interactions

W. Bujalowski and D. PorschKe

Volatile Compounds from Androconial Organs of Danaine and Ithomiine Butterflies

S. Schulz, W. Francke, J. Edgar, and D. SCHNEIDER 
Apomorphine and Haloperidol Influence Electric Behaviour of a Mormyrid Fish

P. KUNZE and H.-U. WeZSTEIN

On the Release and Action of the Hypertrehalosaemic Hormone from the Cockroach Nauphoeta cinerea

G. GäDE

108

Isolation and Characterization of the Androgen Receptor of Murine Preputial Gland

M. Wiegand and K. EISELE

Sedimentation of Nucleoids from Thymic and Splenic Cells of the Rat Following Total-Body $\mathrm{X}$-Irradiation (In German)

K. Tempel and R. HeinzelmanN

Nucleotide Binding and ATPase Activity of Membrane Bound Chloroplast Coupling Factor $\left(\mathrm{CF}_{1}\right)$

B. HUCHZERMEYER

133

Interaction of Ryanodine with the Calcium Releasing System of Sarcoplasmic Reticulum Vesicles

W. Hasselbach and A. Migala

140

The Structure and Function of Grana-Free Thylakoid Membranes in Gerontoplasts of Senescent Leaves of Vicia faba L.

H. O. SCHMIDT

149

Contents of Number $3 / 4$

\section{Original Communcations}

Electron-Energy-Loss-Spectroscopical Investigations on Air Filters for the Analysis of the Air Quality (In German)

B. WOLF

155

Pressure Induced Structural Fluctuations in Hemoglobin, Studied by EPR-Spectroscopy

J. Paul, E. v. Goldammer, and H. R. Wenzel

A Competitive Inhibition Enzyme Immunoassay for Detection and Quantification of Organophosphorus Compounds

P. SChMidt, R. KüHLMANN, and U. Lösch

167
Epicuticular Leaf Waxes of Tilia tomentosa Moənch. and Tilia $\times$ europaea L., Tiliaceae

P.-G. Gülz, E. MülLER, and B. Moog

Lentinellic Acid, a Biologically Active Protoilludane Derivative from Lentinellus Species (Basidiomycetes)

A. Stärk, T. Anke, U. Mocek, W. Steglich, A. KIRFEL, and G. WILL

Phytochemical Investigation of Roots of Pterocarpus marsupium. Isolation and Structural Studies of Two New Flavanone Glycosides

J. TRIPATHI and T. Joshi

184

Dynamics of the Tissue-Specific Metabolism of Luteolin Glucuronides in the Mesophyll of Rye Primary Leaves (Secale cereale)

M. SCHULZ and G. WeISSENBöcK

Molecular Composition of Glutamine Synthetase of Sinapis alba $\mathrm{L}$.

M. HöpfNer, G. Reifferscheid, and A. Wild

Characterization and Localization of Digitoxin $12 \beta$-Hydroxylase from Cell Cultures of Digitalis lanata EHRH

M. Petersen, H. U. Seitz, and E. Reinhard

The Influence of the Proton Gradient on the Activation of Ferredoxin-NADP ${ }^{+}$-oxidoreductase by Light

R. PsChorn, W. RüHLE, and A. Wild 207

Phosphate Binding to Isolated Chloroplast Coupling Factor $\left(\mathrm{CF}_{1}\right)$

B. HUCHZERMEYER

213

Structure of the ATP-Synthase from Chloroplasts and Mitochondria Studied by Electron Microscopy

E. J. Boekema, G. Schmidt, P. Gräber, and J. A. BERDEN

The Position of Carotene in the D-1/D-2 Sub-Core Complex of Photosystem II

S. S. BRODY

226

Solution Conformations of Some Acyclo Nucleoside and Nucleotide Analogues of Antiviral Acyclo- 
nucleosides, and Their Substrate/Inhibitor Properties in Several Enzyme Systems

R. Stolarski, P. Lassota, Z. Kazimierczuk, and D. SHugar

Interaction of Testosterone and Testosterone Receptor Complexes with Nuclei of Skeletal Muscle from Intact Male Mice and from Mice Bearing the Testicular Feminization (Tfm) Mutant Gene

C. Franzelius and K. Eisele

The Effects of the Herbicide Sethoxydim on Transport Processes in Sensitive and Tolerant Grass Species. I. Effects on the Electrical Membrane Potential and Alanine Uptake

A. Weber, E. Fischer, H. Schipp v. Branitz, and U. LÜTTGE

The Effects of the Herbicide Sethoxydim on Transport Processes in Sensitive and Tolerant Grass Species. II. Effects on Membrane-Bound Redox Systems in Plant Cells

A. Weber and U. Lürtge

257

Effect of Inhalation Anesthetics on Spin-Labeled Cholesterol Containing DPPC Vesicles

N. Gulfo, R. BartucCI, and L. Sportelli 264

$\mathrm{SO}_{2}$ Injury in Intact Leaves, as Detected by Chlorophyll Fluorescence

W. Schmidt, U. Schreiber, and W. Urbach 269

Enzymatic Conversion and Degradation of Sex Pheromones in Antennae of the Male Silkworm Moth Antheraea polyphemus

G. Kasang, L. v. Proff, and M. Nicholls 275

Thermodynamic and Magnetic Resonance Studies on the Hydration of Polymers: II. Protein-Water Interactions in Powdered Ribonuclease

H. Janzen, E. Matuszak, E. v. Goldammer, and H. R. WENZEL

285

Growth Control and Pattern Regulation in the Lateral Line Systems of Xenopus

R. Winklbauer

\section{Notes}

Composition of Propolis in Oxfordshire, U.K. and its Relation to Poplar Bud Exudate

W. Greenaway, T. Scaysbrook, and F. R. WHATLEY

301
2',5'-Dihydroxyflavone and its 5'-Acetate - Novel Compounds from the Farinose Exudate of Primula

E. Wollenweber, K. Mann, M. Iinuma, T. TANAKA, and M. MizUno

305

Concentration of Hydroperoxide Lyase Activities in Root of Cucumber Seedlings

A. Hatanaka, T. Kajiwara, and K. Matsui 308

Studies on Columnidin Biosynthesis with Flower Extracts from Columnea hybrida

K. STICH and G. FORKMANN

A New Highly Effective Synthetic Pheromone Mimic for Lobesia botrana (Lepidoptera: Tortricidae) Ch. Brückner, E. Buschmann, R. Becker, W. Seufert, J. J. De Kramer, and W. Krieg 315

Contents of Number $5 / 6$

Original Communications

How Different are the Crystal Structures of Chiral and Racemic Diacylphosphatidylethanolamines?

D. L. DORSET

319

Studies on the Biosynthesis of Pseudoisoeugenols in Tissue Cultures of Pimpinella anisum

R. Martin, G. Schilling, and J. Reichling 328

Three New Benzoic Acid Derivatives from the Glandular Excretion of Eriodictyon sessilifolium (Hydrophyllaceae)

F. J. Arriaga-Giner, E. Wollenweber, I. SCHObER, and G. YATSKIEVYCH

On the Volatile Components of Heterotropa takaoi and Related Species (Aristolochiaceae)

N. Hayashi, Y. Sugiyama, S. Yasuda, and H. KOMAE

341

Biosynthesis of Porphyrinogens in Etiolated Euglena gracilis $\mathrm{Z}$. I. Isolation and Purification of an Endogenous Factor Stimulating the Formation of Porphyrinogens

A. A. Juknat, D. Dörnemann, and H. Senger 
Biosynthesis of Porphyrinogens in Etiolated Euglena gracilis Z. II. Identification of a Regulatory Pteridine

A. A. Juknat, D. Dörnemann, and H. Senger

On the Role of $\Delta 1$-Piperideine and Tripiperideine in the Biosynthesis of Quinolizidine Alkaloids

R. Perrey and M. Wink 363

New Constituents of Essential Oil from Elsholtzia pilosa

H. J. Bestmann, U. Kobold, B. Classen, O. Vostrowsky, G. C. Sah, A. K. Pant, A. B. MelKANI, and C. S. Mathela

Investigation of Ribulose-1,5-bisphosphate Carboxylase-Oxygenase from Tobacco by Small Angle X-Ray Scattering: A Structural Model for the Enzyme in Solution

P. M. Abuja and I. Pilz

Deoxyribonucleotide Biosynthesis in Green Algae. S Phase-Specific Thymidylate Kinase and Unspecific Nucleoside Diphosphate Kinase in Scenedesmus obliquus

B. KLeIN and H. FollmanN

Evidence for Cyclic GMP in the Yeast Saccharomyces cerevisiae, and Studies on Its Possible Role in Growth

H. ECKSTEIN 386

Ribosylation of Mono- and Bicyclic Dicarboxylic Acid Imides (In German)

K.-P. Raezke, H. Frister and E. Schlimme

Effect of Chlorsulfuron, a Potent Inhibitor of Acetohydroxyacid Synthase, on Metabolism of Claviceps purpurea

W. Maier, B. SchumanN, and D. Gröger

403

Fructose-Enhanced Development and Growth of the $\mathrm{N}_{2}$-Fixing Cyanobiont Anabaena azollae

A. Rozen, M. SchöNFELD, and E. TEL-Or

408

The 9-kDa Phosphoprotein Involved in Photoinhibition

M. Kuhn, A. Thiel, and P. Böger

The Development of Daffodil Chromoplasts in the Presence of Herbicides SAN 9789 and SAN 9785 A. HLOUŠEK-RAdoJčIĆ and N. LJubEŠIĆ 418
Lipid Composition of Photosystem I and II ir the Tobacco Mutant Nicotiana tabacum NC 95

J. Bednarz, A. Radunz, and G. H. Schmid 423

Cerulenin-Induced Modifications in the Fatty Acid Composition Affect Excitation Energy Transfer in Thylakoids of Petunia hybrida Leaves

J. A. Graf, K. Witzan, and R. J. Strasser

431

The Role of $\mathrm{Cu}$ in Respiration of Pea Plants and Heterotrophically Growing Scenedesmus Cells

M. Barón Ayala and G. SandmanN 438

Evidence for Photoreduction of $\mathrm{NADP}^{+}$in a Suspension of Lysed Plastids from Etiolated Bean Leaves M. Bertrand, B. Bereza, and E. Dujardin 443

Serological and Structural Comparison of Immunodeficiency Viruses from Man, African Green Monkey, Rhesus Monkey and Sooty Mangabey E. Jurkiewicz, G. Hunsmann, M. Hayami, Y. Ohta, H. Schmitz, and J. Schneider

Primary Cilia in Locust Spermatocytes: Formation, Fate, and Possible Function

A.-M. Daub and M. Hauser

Field Tests with Sex Attractants of Diachrysia chrysitis and D. tutti (Lepidoptera: Noctuidae) at Several Sites in Hungary

M. Tóth, G. Szőcs, J. Molnár, and I. Szarukán

463

Navigation and Compass Orientation by Insects According to the Polarization Pattern of the Sky

K. KIRSCHFELD

467

Notes

Synthesis of Two Allergenic Constituents of Propolis and Poplar Bud Excretion

T. Hashimoto, M. Tori, Y. Asakawa, and

E. WOLLENWEBER

470

3-Hydroxy Retinal, a New Chromophore Identified in Insect Eyes: HPLC Separation and NMR Spectroscopic Identification of the Oxime Forms

W. Gärtner and A. Plangger

473

Demonstrating Evolutionary Relationships Between Macromolecular Sequences through Mutual Relationships with a Third Sequence

M. P. Staves, D. P. Bloch, and J. C. Lacey. jr. 
Contents of Number $7 / 8$

Jriginal Communications

Novel Glucoalkaloids from Rauwolfia Cell Cultures - Acetylrauglucine and Related Glucosides

C. M. Ruyter, H. Schübel, and J. Stöckigt 479

Glycosilation of Terpenols and Aromatic Alcohols by Cell Suspension Cultures of Peppermint (Mentha piperita L.)

R. G. Berger and F. Drawert

485

The Occurrence of Phenols as Degradation Products of Natural Sporopollenin - a Comparison with "Synthetic Sporopollenin"

S. Herminghaus, S. Gubatz, S. Arendt, and R. WIERMANN

491

Two New Enzymes of Rosmarinic Acid Biosynthesis from Cell Cultures of Coleus blumei: Hydroxyphenylpyruvate Reductase and Rosmarinic Acid Synthase

M. Petersen and A. W. Alfermann

501

Biosynthesis of Lipids Containing Isoricinoleic (9-Hydroxy-cis-12-octadecenoic) Acid in Seeds of Wrightia Species

F. Ahmad and K. D. Mukherjee

505

The Occurrence of Tryptamine Derivatives in Psilocybe semilanceata

R. Brenneisen and S. Borner

511

Hydroxylation of Chlorinated and Unchlorinated Chlorophylls in vitro

M. Senge, A. Struck, D. Dörnemann, H. SCHEER, and H. SENGER

515

Synthesis of 2-(E)-O-(4-Hydroxy-cinnamoyl)-D, Lgalactaric Acid, a Presumptive Photosensitive Factor from Glycine max (In German)

H. Schildknecht, H. Sauer, and P. KunzelMANN

519

Elicitation of Pterocarpan Phytoalexins in Cell Suspension Cultures of Different Chickpea (Cicer arietinum L.) Cultivars by an Elicitor from the Fungus Ascochyta rabiei

H. Kessmann, S. Daniel, and W. Barz

529
Elicitor-Induced Changes of Enzyme Activities Related to Isoflavone and Pterocarpan Accumulation in Chickpea (Cicer arietinum L.) Cell Suspension Cultures

S. Daniel, W. Hinderer, and W. Barz

Further Investigations about the Flavin in the L-Amino Acid Oxidase and a Possible Flavin in Photosystem II Complexes from the Cyanobacterium Anacystis nidulans

G. Wälzlein, A. E. Gau, and E. K. Pistorius

Immunochemical Comparative Study on RuBP Carboxylase/Oxygenase of Different Tobacco $\mathrm{Mu}$ tants Exhibiting Different Levels of Photorespiration
A. Radunz and G. H. Schmid
554

Isolation and Purification to Apparent Homogeneity of 4,5-Dioxovalerate Aminotransferase from Scenedesmus obliquus Mutant C-2 A'

A. Kah, D. Dörnemann, and H. Senger

563

The Formation of Phosphate End Groups in the Radiolysis of Polynucleotides in Aqueous Solution Ch. P. Murthy, D. J. Deeble, and C. von SonnTAG

572

Distribution of cis-trans- $\beta$-Carotene in Pigment-Protein Fractions of Photosystem I and II

S. S. Brody, D. Simpson, and M. Rich

Investigation on the Photosynthetic Membranes of Spruce Needles in Relation to the Occurrence of Novel Forest Decline. I. The Photosynthetic Electron Transport

B. Dietz, I. Moors, U. Flammersfeld, W. RüHLE, and A. WILD

581

Investigation on the Photosynthetic Membranes of Spruce Needles in Relation to the Occurrence of Novel Forest Decline. II. The Content of $\mathrm{Q}_{\mathrm{B}}$-Protein, Cytochrome $f$, and P-700

A. Wild, U. Flammersfeld, I. Moors, B. Dietz, and W. RÜHLE

589

Thermoluminescence and Delayed Luminescence Characterization of Photosystem II $_{\alpha}$ and Photosystem $\mathrm{II}_{\beta}$ Reaction Centers

E. Hideg and S. Demeter 596 
Biochemical and Chemical Characterization of Trifluoromethylglyoxal Bis(guanylhydrazone), a Close Analog of the Antileukemic Drug Mitoguazone

H. Elo and I. Mutikainen

601

A Simple, Reliable and Inexpensive Silver Stain for Nerve Fibers in Bleached Skin

B. FRITZSCH and H. H. ZAKON

606

Kinetic Properties of Potassium Stimulated ATPase Purified from Gastric Mucosa

S. TüKEL and T. İsBIR

Discriminative Pheromones of the Social Desert Isopod Hemilepistus reaumuri (In German) H. Schildknecht, U. Esswein, W. Hering, $\mathrm{CH}$. BlaschKe, and K. E. Linsenmair 613

Notes

The Role of Dorsal Rim Ommatidia in the Bee's Eye K. KIRSCHFELD

621

Contents of Number $9 / 10$

\section{Original Communications}

Synthesis of Flavonoid Sulfates. II. The Use of Aryl Sulfatase in the Synthesis of Flavonol-3-sulfates

D. BARRON and R. K. IBRAHIM

625

Synthesis of Flavonoid Sulfates. III. Synthesis of 3',4'-ortho Disulfates Using Sulfur Trioxide-trimethylamine Complex, and of 3'-Sulfates Using Aryl Sulfatase

D. BARRON and R. K. IBRAHIM

631

Wyerol and Wyerone Accumulation in Tissue Cultures of Vicia faba

A. B. Wolff, M. Thynn, E. Görge, and D. WERNER

Metabolism of Ferulic Acid Sucrose Esters in Anthers of Tulipa cv. Apeldoorn: I. The Accumulation of Esters and Free Sugars

P. A. Bäumker, S. Arendt, and R. Wiermann
Metabolism of Ferulic Acid Sucrose Esters in Anthers of Tulipa cv. Apeldoorn: II. Highly Specific Degradation of the Esters by Different Esterase Activities

P. A. Bäumker, S. Arendt, and R. Wiermann

On the Relationships between Molecular Conformation, Affinity towards Penicillin-Binding Proteins, and Biological Activity of Penicillin G-Sulfoxide F. Beise, H. Labischinski, and H. Bradaczek

Semisynthetic Preparation of 1-O-hexadecyl-2-acetyl-sn-glyceryl-3-phosphorylcholine (Platelet Activating Factor)

M. E. LekKa, D. C. Tsoukatos, A. D. Tselepis, and V. M. KaPOULAS

665

Fluorescence Properties of Hog Kidney Aminoacylase I

TH. vom BRUCH and K.-H. RöHM

671

Purification and Characterization of Calcium-Activated Neutral Proteinase from Calf Thymus

M. SCHWENK and E. ZocH

Measuring P700 Absorbance Changes around $830 \mathrm{~nm}$ with a New Type of Pulse Modulation System

U. Schreiber, Ch. Klughammer, and $\mathrm{CH}_{\mathrm{H}}$. NeuBAUER

686

Accumulation of Protoporphyrin IX in the Presence of Peroxidizing Herbicides

G. SANDMANN and P. Böger

QSAR of Nitro-diphenylethers as Inhibitors of Cyclic Photophosphorylation

W. Oettmeier, K. Masson, and A. Donner 705

Mass Spectrometric Analysis of Oxygen Gas Exchange in High- and Low- $\mathrm{CO}_{2}$ Cells of Chlorella vulgaris

Y. Shiraiwa, K. P. Bader, and G. H. Schmid

Immunological Study on the Structural Difference between Ribulose-1,5-bisphosphate Carboxylase/ Oxygenase from Nicotiana tabacum var. John William's Broadleaf and the Tobacco Mutant Su/su C. Nespoulous, P. Fabisch, A. Radunz, and G. H. SCHMID 
Rebinding of the $33 \mathrm{kDalton}$ Polypeptide of Photosystem II to the D-1/D-2 Sub-Core Complex

S. S. BRODY

727

Mammalian Pheromone Studies, VII. Identification of Thiazole Derivatives in the Preorbital Gland Secretions of the Grey Duiker, Sylvicapra grimmia, and the Red Duiker, Cephalophus natalensis B. V. Burger, P. J. Pretorius, J. Stander, and G. R. Grierson

731

Biosynthesis of Pyrrolizidine Alkaloid-Derived Pheromones in the Arctiid Moth Creatonotos transiens: Stereochemical Conversion of Heliotrine

M. Wink, D. SchneIDER, and L. WitTe

737

X-Ray Studies on Phospholipid Bilayers. VIII. Interactions with Chlorpromazine $\cdot \mathrm{HCl}$

M. Suwalsky, L. Gimenez, V. Saenger, and

F. NEIRA

742

Effect of Preparative Procedures on Ghostcells from Bovine Erythrocytes

H. Pitterich and R. Lawaczeck

749

Cell Movement and Symmetry of the Cellular Environment

H. Gruler

754

A New Method to Prepare Sections from Amphibian Embryos for Immunohistology

P. HAUSEN

765

Description of Cell Adhesion by the Langmuir Adsorption Isotherm

K. ECKL and H. GRULER

769

Biological Information Processing Requires Quantum Logic

T. Or

Studies on Malabsorption in Malnourished Pakistani Children

I. Mazahir, M. A. Rahman, and M. A. Arif 782

Notes

Identification and Synthesis of Dimethylalkanes as Sex Attractants of Female Leaf Miner Moths (Lyonetiidae) (In German)

W. Francke, M. Toth, G. Szöcs, W. Krieg,

H. ERNSt, and E. BuschmanN

787
Sex Pheromone of Brinjal Shoot and Pod Borer Leucinodis orbonalis Guenèe (Lepidoptera: Pyralidae: Pyraustinae)

A. B. Attygalle, J. Schwarz, and N. E. GunaWARDENA

790

Evidence of an Intracellular Dissipative Structure

M. A. Medina and I. Núñez de Castro 793

Contents of Number $11 / 12$

\section{Original Communications}

Esters of Caffeic Acid with Aliphatic Alcohols in Bud Exudate of Populus nigra

W. Greenaway, E. Wollenweber, T. ScaysBROOK, and F. R. WHATLEY

795

Triterpenoids in Epicuticular Waxes of Three European Euphorbia Species

H. Hemmers, P.-G. Gülz, and F.-J. Marner 799

Organ Specific Composition of Epicuticular Waxes of Cistus albidus L., Cistaceae

S. Hennig, P.-G. Gülz, and K. Hangst 806

Dimers of Altersolanol A from Alternaria solani

G. Lazarovits, R. W. Steele, and A. Stoessl 813

Major Flavanones from Lonchocarpus guatamalensis J. L. Ingham, S. Tahara, and St. Z. Dziedzic 818

Chemical Analysis of Peptidoglycans from Species of Chromatiaceae and Ectothiorhodospiraceae

J. Meissner, U. J. Jürgens, and J. Weckesser 823

Characterization of Hexokinase and Fructokinase from Suspension-Cultured Catharanthus roseus Cells

Y. Yamashita and H. Ashihara

827

Enzymatic Studies on the Reversible Synthesis of Nicotinic Acid-N-glucoside in Heterotrophic Parsley Cell Suspension Cultures

B. Upmeier, J. E. ThomziK, and W. BARz 835

Glutaric Acid as a Catabolite of Nicotinic Acid in Parsley Cell Suspension Cultures

D. Komossa and W. BARZ

843 
Acetolactate Synthase from Barley (Hordeum vulgare L.): Purification and Partial Characterization J. DURner and P. Böger

850

Structure-Activity Relationships and Physiological Aspects of New Photosynthetic Electron Transport Inhibitors, 3-Alkylaminoalkyliden- $\mathrm{H}$-pyran2,4(3H)-diones (APs)

T. Asami, H. Koike. Y. Inoue, N. Takahashi, and $\mathrm{SH}$. Yoshida

857

Accumulation of a Novel Red Pigment in Cell Suspension Cultures of Floral Meristem Tissues from Carthamus tinctorius L.

K. Saito, E. Daimon, K. Kusaka, S. Wakayama, and Y. SEKINO

862

Photoinhibition of Electron Transport Activity of Photosystem II in Isolated Thylakoids Studied by Thermoluminescence and Delayed Luminescence I. Vass, N. Mohanty, and S. Demeter

871

Kinetic Relationship between Energy-Dependent Fluorescence Quenching, Light Scattering, Chlorophyll Luminescence and Proton Pumping in Intact Leaves

W. Bilger, U. Heber. and U. Schreiber 877

Dark and Photohemolysis of Erythrocytes by Furocoumarins

D. Vedal.di, S. Caffieri, G. Miolo, F. DalL'AcQua, and P. Arsi.AN

888

Heme-Activated Oxidations by the Chlorite-Oxygen Complex "TCDO" (OXOFERIN ${ }^{\circledR}$ ) (In German) E. F. El.stner

893

Tissue-Specific Incorporation of Azadirachtin in the Malpighian Tubules of Locusta migratoria

H. Rembold, Th. Müller, and B. SubrahMANYAM

903

Azadirachtin-Induced Sterilization in Mature Females of Rhodnius prolixus

D. Feder, D. Vali.e, H. Rembold, and E. S. GARCIA 908

Identification of Major Lipids from the Scent Gland Secretions of Dumeril's Ground Boa (Acrantophis dumerili Jan) by Gas Chromatography-Mass Spectrometry

J. T. Simpson. P. J. Weldon, and Th. R. Sharp
Secondary Sex Pheromone Components of Choristoneura murinana $\mathrm{Hb}$. (Lepidoptera: Tortricidae)

E. Priesner, H. Bogenschütz, and $\mathrm{CH}_{\text {H. Löfstedt }}$

Pressure Effects on the Interactions of the Sarcoplasmic Reticulum Calcium Transport Enzyme with Calcium and Dinitrophenyl Phosphate

W. Hassel.BaCh

Spontaneous Formation of Giant Phospholipid Vesicles

R.-M. Servuss

9.38

Assessment of Persisting Chromosome Aberrations by Flow Karyotyping of Cloned Chinese Hamster Cells

F. J. Oтто 948

Trichoplax adhaerens F. E. Schulze (Placozoa): The Formation of Swarmers

M. Thiemann and A. Ruthmann 955

Notes

The Odor-Bouquet of Ips schmutzenhoferi Holzschuh (Col.: Scol.)

W. Francke, J. Barteis, H. Schmutzenhofir.

U. KoHNi.E, and J. P. Vitŕ:

958

(Z)-3- and (Z)-5-Decenyl Acetates. Sex-Attractant Components for Male Eustrotia uncula $\mathrm{Cl}$. (Lepidoptera: Noctuidae)

E. PRITSNI:R

961

Stability of Ferricinium and its Cytostatic Effect

(In German)

M. Wenzei, Y. Wu, E. Liss, and E. W. Neusf:

96.3

Do Monoclonal Antibodies Recognize Linear Sequential Determinants?

M. Camera. E. Muratti. M. L. Trinca, and

A. Chersi 967

Subject Index

971

Authors Index

992 


\title{
Conformational Studies of Biliproteins from the Insects Pieris brassicae and Cerura vinula
}

\author{
Hugo Scheer \\ Botanisches Institut der Universität, Menzinger Straße 67, D-8000 München. \\ Bundesrepublik Deutschland
}

Hartmut Kayser*

Abteilung für Allgemeine Zoologie der Universität. Oberer Eselsberg. D-7900 Ulm. Bundesrepublik Deutschland

Z. Naturforsch. 43c, 84-90 (1988); received August 26. 1987

Biliverdin IX $\gamma$, Chromophore Conformation. Phycocyanin, Pieris brassicae, Cerura vinula

Chromophore conformation and protein secondary structure of biliproteins from the butterfly, Pieris brassicae, and the moth, Cerura vinula, have been investigated by absorption, circular dichroism and fluorescence spectroscopy. The chromophore of the $P$. brassicae protein. biliverdin IX $\gamma$, has probably a cyclic-helical structure similar to that of free bile pigments of the biliverdin type. Though achiral by structure the chromophore displays strong optical activity in the native protein-bound state, but becomes inactive after urea denaturation of the protein. A minor biliprotein from $P$. brassicae shows absorption. circular dichroism and fluorescence spectra identical to the main biliprotein. In the biliprotein from Cerura vinula the structure of the pigment is still unknown. It has a semi-open conformation intermediate between that of the Pieris proteins and that of the phycobiliprotein. C-phycocyanin, and it retains optical activity after urea denaturation. The band widths and the size of the Stokes shifts of the fluorescence spectra indicate a high degree of conformational flexibility of the chromophores in the two Pieris pigments, and a decreased flexibility in the one from Cerura. In the biliproteins from both insects the polypeptides are low in $\alpha$-helix content compared to that of phycobiliproteins. From these and earlier data. insect and algal biliproteins seem to be related only distantly if at all. but there exist also considerable differences among insect biliproteins from different species.

\section{Introduction}

Insect biliproteins are different from those of other organisms in several respects [1]. Unlike the phycobiliproteins, antenna pigments from several algal phyla [2], their chromophores are non-covalently bound to the apoproteins. Unlike all mammalian and plant bile pigments, they also contain chromophores of the IX $\gamma$-series which are derived from cleavage of the porphyrin precursors at the C-15 (formerly $\gamma$ ) methine bridge [ $3 \mathrm{a}$ ]. The function of insect bile pigments is presently still unclear [1]. In combination with yellow carotenoids they provide strongly green. but non-fluorescent and thus non-phototoxic colors for camouflage. In addition more active roles have recently been suggested [3b] which depend on their polychromic properties [2] influenced e.g. by conformation, state of protonation, etc.

\footnotetext{
* Present address: Ciba-Geigy AG, R-1093.P.39. Postfach, CH-4002 Basel. Switzerland.

Reprint requests to Prof. Dr. H. Scheer.

Verlag der Zeitschrift für Naturforschung. D-7400 Tübingen $0341-0382 / 88 / 0100-0084 \$ 01.30 / 0$
}

Here, we wish to present further results [4] from absorption and circular dichroism studies, which indicate that both the chromophore conformation and protein secondary structure show distinct differences among different insect biliproteins, but that they are at the same time profoundly different from the well characterized phycobiliproteins $[2,5$ a] . To date no information on these points had been obtained from insect biliproteins (see note). The pigments under study were two isoforms from the butterfly, Pieris brassicae, [5b] and a very different biliprotein from the moth, Cerura vinula (Kayser, unpublished).

\section{Materials and Methods}

\section{Preparations}

Details of the preparation of the biliproteins and their apoproteins from Pieris brassicae L. will be published elsewhere [5b]. Briefly, the holoproteins were extracted from whole adult insects with $0.2 \mathrm{M}$ potassium phosphate $\mathrm{pH}$ 7.2. The purification procedure involved chromatofocussing on a PBE 94 (Pharmacia) column with Polybuffer 74 adjusted to $\mathrm{pH} 5.0$ as eluant. This step yielded a main biliprotein I and a 
minor fraction, biliprotein II, in essentially pure form as judged from their absorptions at 383 and $280 \mathrm{~nm}$. After removal of Polybuffer on a phenylsepharose column, and of salt by ultrafiltration the proteins were lyophilized. The apparent molecular weight was determined by SDS-polyacrylamide gel electrophoresis to $22.5 \mathrm{kDa}$. The following extinction coefficients were obtained: Holoprotein: $280 \mathrm{~nm}$ (64200), $383 \mathrm{~nm}$ (64200), $675 \mathrm{~nm}\left(36300 \mathrm{~cm}^{-1} \mathrm{M}^{-1}\right)$. Apoprotein: $\quad 280 \mathrm{~nm} \quad\left(48100 \mathrm{~cm}^{-1} \mathrm{M}^{-1}\right)$. The chromophore-apoprotein stoichiometry is $1: 1$ in both biliproteins from Pieris.

The biliprotein from Cerura vinula L. was obtained from larval haemolymph by chromatography on DEAE-cellulose (Kayser, unpublished results). On the basis of SDS-PAGE its molecular size was estimated to $80-85 \mathrm{kDa}$ and its purity to $95 \%$.

Absorption spectra were recorded with a model 320 spectrophotometer (Perkin-Elmer, Überlingen), fluorescence spectra with a model fluorolog spectrofluorometer (Spex) with a data acquisition system. Circular dichroism spectra were measured with a dichrograph V (Jobin-Yvon, Unterhaching). The optical density for $\mathrm{CD}$ measurements was $\leq 0.5$. and the pathlength $1 \mathrm{~cm}$ in the visible and near-UV, $0.1 \mathrm{~cm}$ in the far-UV. Secondary structure of the proteins was estimated from an analysis of the farUV CD spectrum using the program of Provencher and Glöckner [6].

\section{Results}

\section{Absorption spectra}

The absorption spectrum of the Pieris biliprotein I (the main fraction) has a broadened visible absorption band indicative of two superimposed component bands (Fig. 1a). The near UV band is structured, too. The intensity ratio of the maximum absorption $Q^{\mathrm{A}}$ visur of the visible to that of the near UV band is 0.56 . The maximum absorptivity of the aromatic amino acids ( $280 \mathrm{~nm}$, not shown) is the same as that of the near UV band. The absorption spectrum of the minor biliprotein II is identical to that of the main fraction (not shown).

The absorption spectrum of the Cerura biliprotein (Fig. 2a) is considerably different. The visible band is structured, too, but has only a pronounced shortwavelength shoulder and is much more increased in intensity relative to that of the near UV band $\left(Q^{A}{ }_{\text {vis'uv }}\right.$ $=1.22$ ). The intensity of the band arising from the aromatic amino acid residues is $7-8$ times that of the near UV band.

\section{Circular dichroism spectra}

The CD spectrum of the Pieris protein I (Fig. 1b) has a positive visible and a negative near UV band, whose structure follows closely that of the absorption spectrum (Fig. 1a). The intensity ratio (maximum ellipticities) in the $C D$ spectrum is slightly smaller (0.49) than in the absorption spectrum. In the biliprotein II no difference to protein I was observed.

The same correspondences with the absorption spectra are seen in the CD spectrum of the Cerura pigment. The fine structure is again very similar to that of the absorption spectrum, and the intensity ratio of the visible and near UV band is also smaller (0.89).

(a)

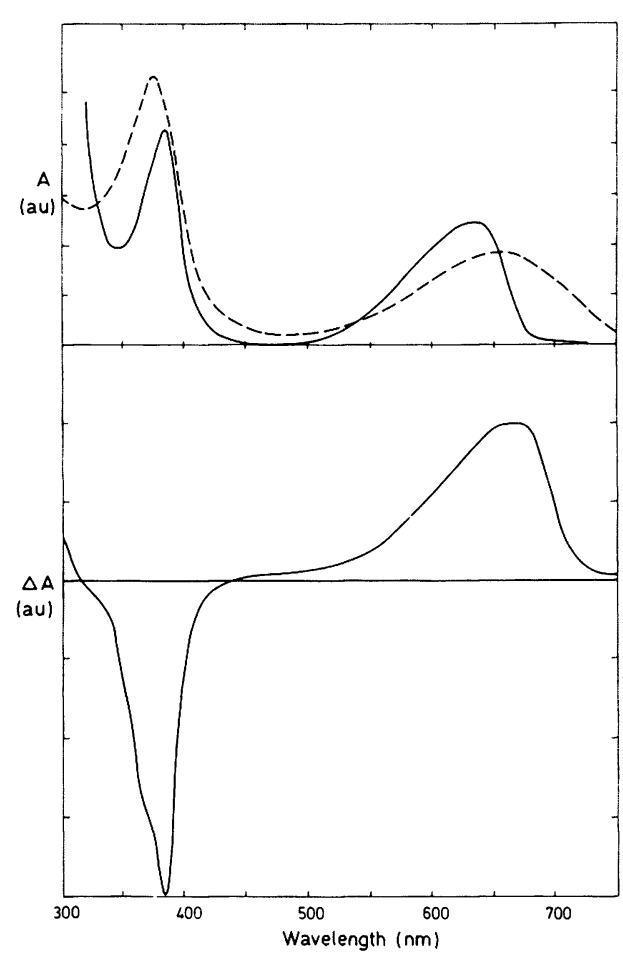

Fig. 1. Absorption (a) and circular dichroism spectra (b) of the biliprotein I from Pieris brassicae. The spectra of the native pigment $(50 \mathrm{~mm}$ potassium phosphate buffer, $\mathrm{pH}$ 6.9, solid lines) are compared to those of the denatured pigments in $8 \mathrm{M}$ urea solution (dashed lines). See experimental part for molar extinction coefficients and ellipticities. 
(a)

(b)

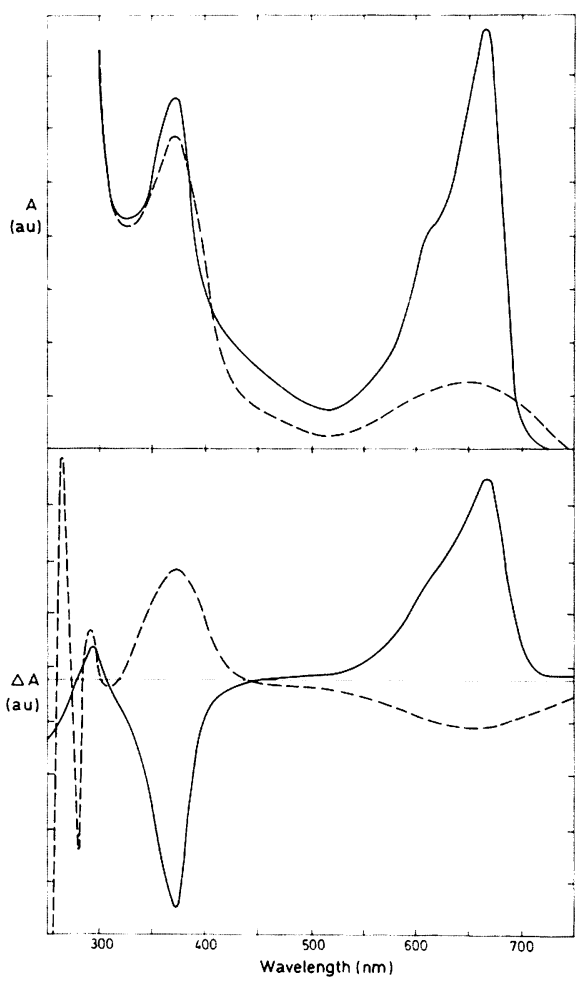

Fig. 2. Absorption (a) and circular dichroism spectra (b) of the biliprotein from Cerura vinula. Other details as in Fig. 1.

\section{Fluorescence spectra}

The main emission of the Pieris biliprotein $I$ is at $705 \mathrm{~nm}$ (Fig. 3). This maximum is independent of the excitation wavelength and corresponds to a Stokes shift of appx. $50 \mathrm{~nm}$, with the exact value depending on the assumed position of the rather flattopped absorption band. If the excitation wavelength is shifted below $320 \mathrm{~nm}$ a second emission band arises at $641 \mathrm{~nm}$, which becomes most prominent at excitations below $280 \mathrm{~nm}$. This indication of two emitting species being present, is supported by the excitation spectra. Whereas the excitation spectrum with observation at $705 \mathrm{~nm}$ is dominated by a structured near UV band $\left(\lambda_{\max }=384 \mathrm{~nm}\right)$, an excitation band at $288 \mathrm{~nm}$ becomes more prominent at shorter observation wavelengths. The properties of the biliprotein II from this species are again very similar.

The main emission of the Cerura biliprotein (Fig. 4) is located at $691 \mathrm{~nm}$ corresponding to a Stokes shift of only $25 \mathrm{~nm}$. Here, too, a shorter
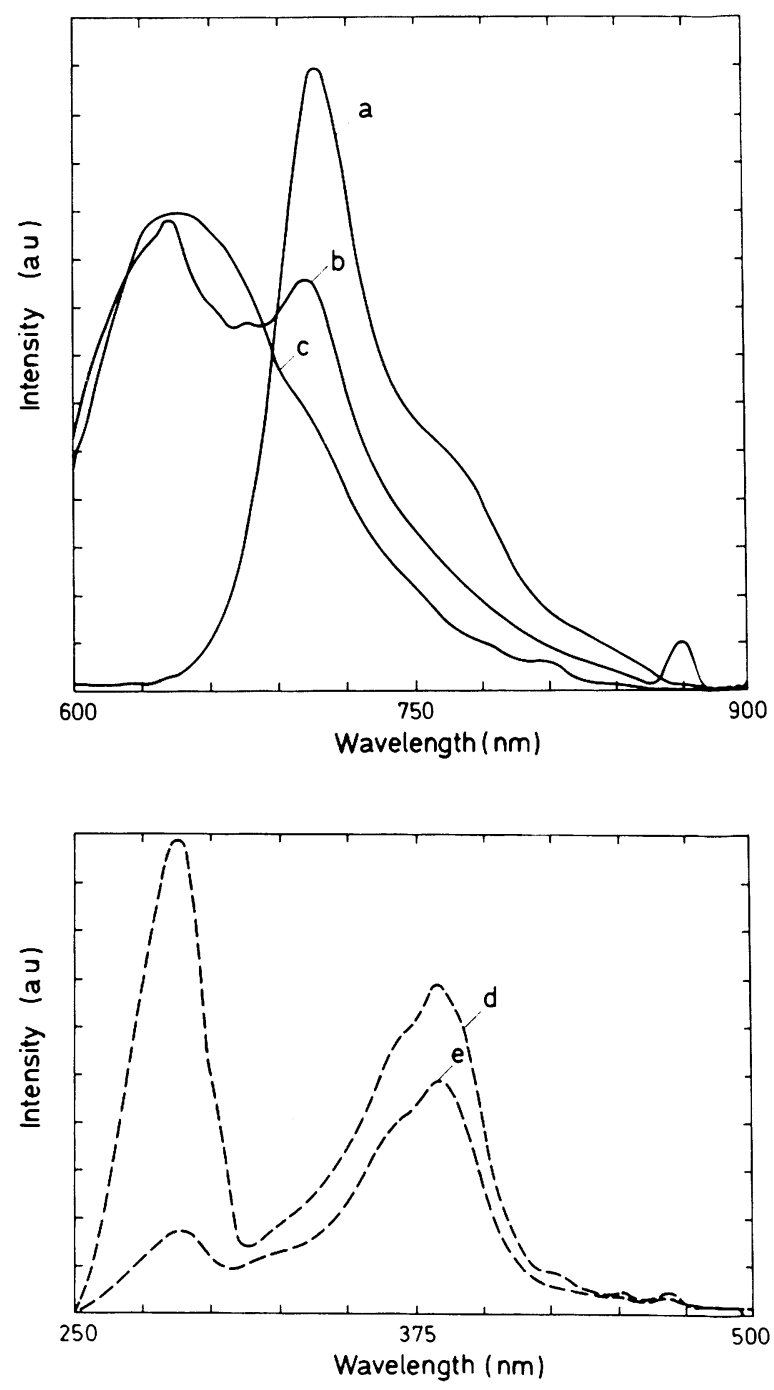

Fig. 3. Fluorescence spectra of the biliprotein I from Pieris brassicae. Emission spectra (solid lines): excitation at 382 (a). 290 (b) and $270 \mathrm{~nm}$ (c). Excitation spectra (dashed lines): emission at 675 (d) and $705 \mathrm{~nm}$ (e). All spectra are uncorrected.

wavelength emission $\left(\lambda_{\max }=6.32 \mathrm{~nm}\right)$ is observed upon excitation below $300 \mathrm{~nm}\left(\lambda_{\max }=297 \mathrm{~nm}\right)$.

\section{Protein conformation and stability}

The protein secondary structure was estimated from the far UV-CD spectrum by an analysis based on a set of standard proteins of known secondary structure composition [6]. The data for biliprotein I from Pieris and for the Cerura protein are shown in 

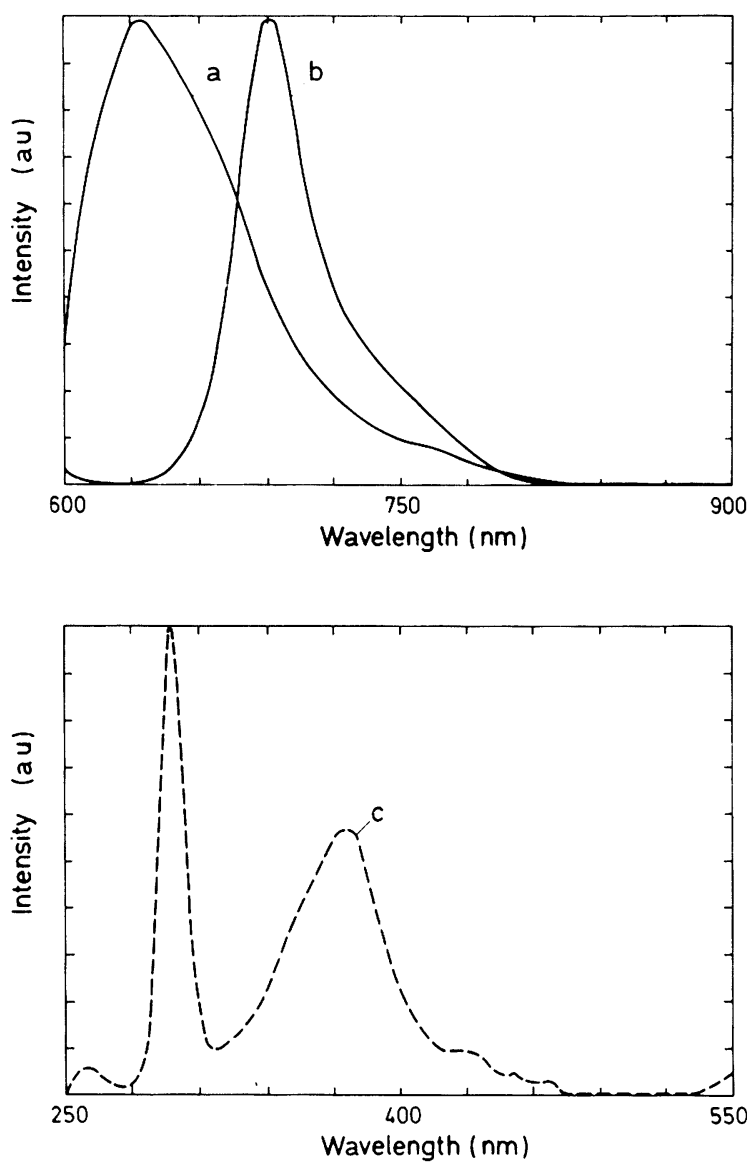

Fig. 4. Fluorescence spectra of the biliprotein from Cerura vinula. Emission spectra (solid lines) with excitation at 370 (a) and $256 \mathrm{~nm}$ (b). excitation spectrum (dashed line) with emission at $691 \mathrm{~nm}(\mathrm{c})$.
Table I together with those for the phycobiliprotein, C-phycocyanin from Mastigocladus laminosus. Although the precision of the method is limited by the relatively poor signal-to-noise ratio in the case of the insect biliproteins, it is clear that the $\alpha$-helix content is much smaller in both pigments than in the phycobiliproteins. A comparison of the Pieris chromoprotein with the apoprotein also indicates a decreased $\alpha$-helix content in the latter.

Upon titration of the Pieris protein I with urea, the far-UV CD band decreases monotonously and also shifts to longer wavelengths (Table I, Fig. 5). The analysis suggests a rapid loss of $\alpha$-helix structure. whereas the estimates for $\beta$-sheet remain high up to $8 \mathrm{~m}$ urea. The process has been monitored, too, by observation of the absorption and CD spectra in the chromophore region. In the absorption spectrum, the most pronounced change is a loss of fine structure in both the visible and the near UV bands (Fig. 1 and 5). By contrast, the intensity ratio and position of the two bands remain nearly the same. The optical activity decreases to less than $1 \%$ of its original value in the native pigment during unfolding. In comparison to the monotonous decrease of the far-UV CDband, the decrease in the visible and near-UV is largest between 0 and $2 \mathrm{~m}$ and above $4 \mathrm{~m}$ urea, whereas the change between 2 and $4 \mathrm{~m}$ urea is only very small. This behavior has been reproduced in three different titrations.

Due to the optical activity being so sensitive to the native state of the protein, it was also used to test the stability towards acid and base. Whereas the bilipro-

Table I. Secondary structures of insect biliproteins. Estimated from the far-UV CD spectra by the method of Provencher and Glöckner [6]. We thank the authors for a copy of the CONTIN program. The data used are the ones shown in Fig. 2 and 5.

\begin{tabular}{|c|c|c|c|}
\hline (Chromo)protein & $\begin{array}{l}\text { Second } \\
\alpha \text {-helix }\end{array}$ & $\begin{array}{c}y \text { structure } \\
\beta \text {-sheet }\end{array}$ & $\begin{array}{l}{[\%]} \\
\text { others }\end{array}$ \\
\hline Pieris brassicae (I) Holoprotein & 23 & 47 & 30 \\
\hline Pieris brassicae (I) Holoprotein. $2 \mathrm{M}$ urea & 5 & 57 & 35 \\
\hline Pieris brassicae (I) Holoprotein. $+\mathrm{M}$ urea & 6 & 42 & 52 \\
\hline Pieris brassicae (I) Holoprotein. 6 $\mathrm{M}$ urea & 0 & 50 & 50 \\
\hline Pieris brassicae (I) Holoprotein, $8 \mathrm{M}$ urea & 7 & 42 & 51 \\
\hline Pieris brassicae (I) Apoprotein & 13 & 55 & 32 \\
\hline Cerura vinula Holoprotein & 18 & 58 & 24 \\
\hline Mastigocladus laminosus Phycocyanin & 85 & 7 & 8 \\
\hline
\end{tabular}




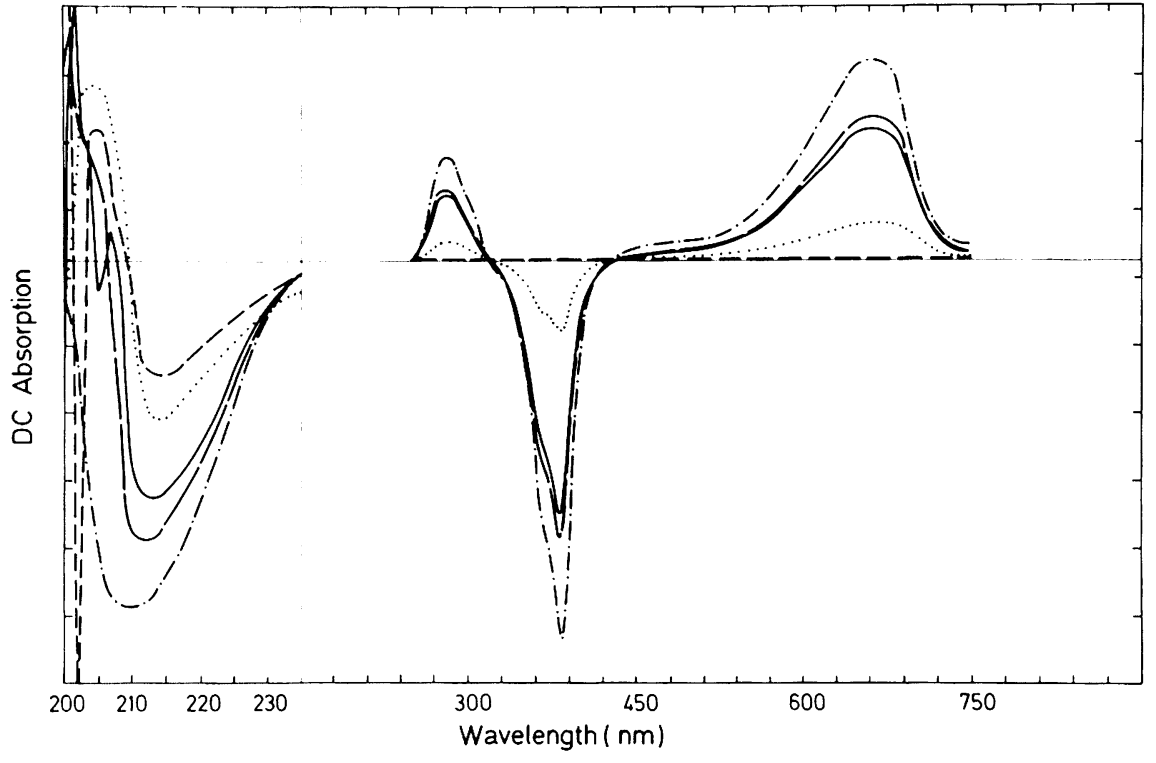

Fig. 5. Unfolding of the polypeptide chain of the Pieris chromoprotein I with urea as monitored by CD spectroscopy. The ordinate in the left part $(\leq 240 \mathrm{~nm})$ is decreased by a factor of ten relative to that of the right part $(\geq 280$ $\mathrm{nm})$. See Table I for molar ellipticities. $(-\cdots)=$ Original solution. as in Fig. 1: (- - ) $=2 \mathrm{M}$ urea. $(\longrightarrow)=4 \mathrm{~m}$ urea, $(\cdots \cdots)=6$ m urea. $(-\cdots)$ $=8 \mathrm{~m}$ urea. tein I from Pieris was quite stable towards acid, treatment with base led to unfolding of the protein (Table II). In this respect, incubation at $\mathrm{pH} 9.5$ was equivalent to a urea concentration of appx. $4 \mathrm{~m}$.

Table II. pH Stability of biliprotein I from Pieris brassicae. Optical activity of the chromophore absorption bands (in $\%$ relative to $\mathrm{pH} 7$ ), and ratios of the CD signal maximum amplitudes $Q^{\mathrm{CD}}$ visnuv.

\begin{tabular}{lrrl}
\hline $\mathrm{pH}$ & $\delta \overline{\mathrm{A}}_{\text {vis }}$ & $\delta \overline{\mathrm{A}}_{\text {tur }}$ & $Q^{(\mathrm{C})}{ }_{\text {vis inu }}$ \\
\hline 2.9 & $98 \%$ & $88 \%$ & 0.50 \\
6.4 & $100 \%$ & $100 \%$ & 0.45 \\
9.5 & $60 \%$ & $56 \%$ & 0.48 \\
\hline
\end{tabular}

The changes in the Cerura pigment upon unfolding of the protein, have been investigated less extensively due to the limited availability of the material. The absorption and CD spectra of the fully denatured pigment $(8 \mathrm{~m}$ urea) are shown in Fig. 2. Two points are noteworthy: Firstly, the absorption spectrum of the denatured pigment has a markedly changed $Q_{\text {visiu }}^{\text {A }}$, which is decreased by a factor of 6 to 0.22 , with a concomitant blue-shift of the visible band. Secondly, the circular dichroism remains considerable after unfolding, but the sign of both bands is inverted as compared to the native state of this pigment.

\section{Discussion}

\section{Pieris brassicae biliproteins}

The spectra of bile pigments are sensitive to a variety of factors. The most important one seems to be the geometry of the chromophore. This has been born out of a series of molecular orbital calculations performed in different laboratories [7-11]. and more recently corroborated experimentally $[3,5 \mathrm{a}$, 12-15]. Whereas the cyclic-helical chromophores typical for bile pigments in solution have a low ratio $Q^{A}{ }_{\text {vis nu }}$ of the intesities of the visible and near-UV absorption bands, this ratio is high in extended chromophores like the ones in native phycocyanins [5a], and in the neobiliverdins found first in insects [3], and more recently in other invertebrates [16].

As judged from this criterion. the chromophores of the Pieris biliproteins I and II are present in a cyclic-helical conformation which is quite similar to that of the respective free chromophore, which is present e.g. after denaturation of the polypeptide (Fig. 1). The main difference is, that the conformational freedom [2] seems to be somewhat more restricted in the native biliprotein, leading to the structured absorption bands. However, the large Stokes shift $(50 \mathrm{~nm})$ is still indicative of a mobile chromophore. Recent kinetic fluorescence data also indicate a high degree of similarity between the native Pieris pigment and free bile pigments as far as 
conformation and conformational freedom is concerned [17]. In the phycobiliproteins, partial loosening of the interactions with the proteins, e.g. by partial denaturation of the latter, leads to photochromic behavior resembling the primary reactions of phytochrome, which is again lost when the protein is fully uncoupled [4]. Similar studies with the Pieris biliprotein I did not show any photochemistry besides bleaching upon prolonged irradiation, which would also support that the chromophore reactivity is similar to that of free biliverdins.

Binding to the protein does induce, however, a strong optical activity. Since the chromophore, biliverdin IX $\gamma$, is achiral, this optical activity must be induced by the protein. Probably, a similar mechanism is operative as in the complexes of bile pigments to serum albumin $[9,18]$, where it has been rationalized by preferential binding of one enantiomeric form of the helical chromophore to the chiral protein. This situation is quite different from the phycobiliproteins, e.g. phycocyanin [2, 5a], where inherently optically active chromophores are bound covalently in extended conformations to the apoproteins.

The secondary structure of the apoprotein is considerably different, too, from that of apophycocyanin. The latter is related to the globins [5a] and contains a large proportion of $\alpha$-helix structure. In the case of C-PC from Mastigocladus laminosus, the $\mathrm{x}$-ray results give $\alpha$-helix contents of 65 and $62 \%$ for the $\alpha$ - and $\beta$-subunits, respectively. When estimated [6] from the far-UV CD spectrum, an even larger value of $85 \%$ is obtained (Table I). Similarly high contents are also obtained by $\mathrm{CD}$ analysis of another biliprotein, the plant photomorphogenetic pigment phytochrome [19]. The shape of the far-UV CD spectrum of the Pieris pigments with a single. unstructured negative band in the $200-225 \mathrm{~nm}$ region, is already indicative of a low content in $\alpha$-helix. The curve resolution [6] yields a content of only $23 \%$ $\alpha$-helix, about $50 \% \beta$-sheet, and a high amount of "other" secondary structures.

In summary, the two Pieris biliproteins are thus so different from the phycobiliproteins that a relationship seems very unlikely. Their chromophore, biliverdin IX $\gamma$, differs fundamentally from the that of the algal proteins in its molecular structure, binding situation and conformation, and the secondary structure of the apoproteins is also basically different from that of the phycobiliproteins. However, no significant differences were found between the two isoproteins from Pieris.

\section{Cerura biliprotein}

The biliprotein from Cerura has been included in this study in order to compare the Pieris pigments to another insect biliprotein. It is less well characterized to date (Kayser, unpublished) and in particular is the chromophore molecular structure yet unknown. The spectral data presented here show, that the chromophores of these two insect biliproteins and their binding situation are likely to be quite different. They indicate the following structural elements: The chromophore does not appear to belong to the class of neobilins [3]. In these pigments, the additional bridges between the pyrrole rings lead to a fixation of more extended conformations, which are characterized by an increased $Q^{A}$ vis/uv value. In the denatured Cerura pigment, this ratio is rather similar to that of classical biliverdins and thus indicative for the absence of additional bridges.

The moderately strong CD signal in the denatured protein indicates furthermore, that the chromophore is optically active, e.g. that it contains an asymmetric $\mathrm{C}$-atom or another chiral element. Induced optical activity by the protein should be negligible under these conditions. Strong optical activity can be induced in bile pigments by an intramolecular induction mechanism first proposed by Moscowitz et al. [20]. It originates from the fact that bile pigments in cyclic-helical conformations are present in two enantiomeric forms differing in the sense of their helice. Since these are inherently dissymmetric, a small shift in the distribution of these two enantiomeric forms by asymmetric centers on the molecule can produce large anisotropies. In contrast to the asymmetric induction by the matrix, e.g. a binding protein (see above), this intramolecular asymmetric induction persists after the unfolding of the protein, as shown for the phycobiliproteins [21].

The binding site of the Cerura protein also seems to be different from that of the Pieris proteins. The increased ratio $Q^{\mathrm{A}}$ vis/uv suggests a more extended conformation for the chromophore, which is intermediate between the latter and C-phycocyanin. Due to the comparably small increase, the situation is less clear-cut, however, than in the phycobiliproteins. Principally, the increased intensity of the visible absorption band can be rationalized as well by a proto- 
nation of the chromophore [22]. However, protonation is accompanied by a pronounced red-shift of this band, which does not seem to be present in the $\mathrm{Ce}$ rura pigment (Fig. 2a). The biliprotein from Cerura would then be the first example of a biliprotein with an (at least partly) extended chromophore besides the plant- and phycobiliproteins.

The secondary structure of the Cerura biliprotein is again similar to the one from Pieris in its low $\alpha$ helix content. Curve resolution of the far-UV CD spectrum yields values of $13 \% \alpha$-helix, $55 \% \beta$-sheet and $32 \%$ "others". In view of the relatively poor signal-to-noise and the unknown precise molecular weight, these values should be regarded as rough estimates only. Nonetheless is the secondary structure of the Cerura protein, like that from Pieris, quite distinct from that of the well characterized phycobiliproteins.

\section{Conclusions}

The data suggest that insect biliproteins have several distinct conformational differences which set them apart from the plant and phycobiliproteins and render a phylogenetic relationship unlikely. The secondary structure of the polypeptides of the three insect pigments investigated, seems to be more closely

[1] H. Kayser, in: Comprehensive Insect Physiology. Biochemistry, and Pharmacology (G. A. Kerkut and L. I. Gilbert. eds.), chapter 11. pp. 367-415. Pergamon Press. New York 1985.

[2] H. Scheer, in: Light reaction path of photosynthesis (F. K. Fong. ed.) chapter 2, pp. 7-45. Springer Verlag. Berlin 1983.

[3] a: M. Bois-Choussy and M. Barbier. Heterocycles 9, $677-690$ (1978).

b: M. Barbier. Comp. Biochem. Physiol. 84b, 619-621 (1986).

[4] W. John. R. Fischer, S. Siebzehnrübl, and H. Scheer, in: Antennas and Reaction Centers of Photosynthetic bacteria (M. E. Michel-Beyerle. ed.). pp. 17-25. Springer Verlag. Berlin-Heidelberg 1985.

[5] a: T. Schirmer, W. Bode, R. Huber. W. Sidler, and H. Zuber. J. Mol. Biol. 184, 257-277 (1985).

b: H. Kayser and D. Zipfel, manuscript in preparation.

[6] S. W. Provencher and J. Glöckner. Biochemistry 20, 33-37 (1981).

[7] M. I. Burke. L. H. Pratt, and A. Moscowitz. Biochemistry 11, 4025-4031 (1972).

[8] Q. Chae and P. S. Song. J. Am. Chem. Soc. 97, 4176-4179 (1975)

[9] G. Wagnière and G. Blauer. J. Am. Chem. Soc. 98, $7806-7810(1976)$.

[10] T. Sugimoto. M. Kikushima. M. Saito, and H. Suzuki. J. Phys. Soc. Jpn. 53, 873-881 (1984). related. However, the pigments from Pieris and $\mathrm{Ce}$ rura differ markedly in the molecular structure and the native conformation of their chromophores. Together with the large difference in molecular weight, this suggests a considerable variability among the insect biliproteins.

\section{Acknowledgements}

This work was supported from the Deutsche Forschungsgemeinschaft. Bonn (H.S.: Forschergruppe "Pflanzliche Tetrapyrrole", H.K.: SFB 87-A2). The expert technical assistance of $\mathrm{C}$. Bubenzer and $\mathrm{S}$. Schoy is acknowledged. We thank J. Gottstein (München) for the recording of the fluorescence spectra, and S. Siebzehnrübl for the photochemical tests.

Note: After preparation of this manuscript, the x-ray structure analysis and a preliminary molecular model for the biliprotein I (termed bilin binding protein. BBP) from Pieris brassicae has been published (R. Huber, M. Schneider, O. Epp, I. Mayr. A. Messerschmidt, J. Pflugrath, and H. Kayser: J. Mol. Biol. 195, 423-434, 1987). The data support and detail the conformational assignments as given in our present work and also the large differences between insect and cyanobacterial biliproteins.

[11] H. Scheer, H. Formanek, and S. Schneider. Photochem. Photobiol. 36, 259-272 (1982)

[12] H. Falk. K. Grubmayr. E. Haslinger, T. Schlederer, and K. Thirring. Monatsh. Chem. 109, 1451-1473 (1978)

[13] H. Nesvabda and A. Gossauer. J. Am. Chem. Sux. 109, 6545-6546 (1987).

[14] H. Falk and K. Thirring. Tetrahedron 37, 761-766 (1981)

[15] S. E. Braslavsky, A. R. Holzwarth, and K. Schaffner. Angew. Chem. 95, 670-689 (1983): Angew. Chem. Int. Ed. 22, 656-675 (1983).

[16] E. Benedikt. Ph. D. Thesis. Universität München 1987.

[17] S. Schneider. F. Baumann. P. Geiselhart. H. Kayser. and H. Scheer, Photochem. Photobiol., submitted for publication (1987).

[18] G. Blauer and G. Wagnière, J. Am. Chem. Soc.97, $1949-1955$ (1975).

[19] E. M. Tobin and W. R. Briggs. Photochem. Photobiol. 18, 487 (1973).

[20] A. Moskowitz, W. C. Krueger. I. T. Kay, G. Skewis. and S. Bruckenstein. Proc. Natl. Acad. Sci. USA $5 \mathbf{2}$, $1190-1194$ (1964).

[21] H. Lehner and H. Scheer, Z. Naturforsch. 38; $353-358$ (1983).

[22] H. Scheer. Z. Naturforsch. 31 c, 413-417 (1976). 